\title{
PRONUNCIATION LEARNING, PARTICIPATION, AND ATTITUDE ENHANCEMENT THROUGH MOBILE ASSISTED LANGUAGE LEARNING (MALL)
}

\author{
Alfi Hidayatu Miqawati \\ Department of English Study Program, Language, Communication and Tourism, \\ Politeknik Negeri Jember, Indonesia \\ E-mail: alfi_hidayatu@polije.ac.id
}

\begin{abstract}
APA Citation: Miqawati, A. H. (2020). Pronunciation Learning, Participation, and Attitude Enhancement through Mobile Assisted Language Learning (MALL). English Review: Journal of English Education, 8(2), 211-218. doi: 10.25134/erjee.v8i2.2118.
\end{abstract}

Received: 29-01-2020

Accepted: 20-03-2020

Published: 01-06-2020

\begin{abstract}
A mobile application, Tflat English Pronunciation, is proposed in the teaching of pronunciation for it possesses features that can assist students when learning how to enunciate English words and identify English phonemic symbols. Thus, this study presents the results of the implementation of Tflat English Pronunciation mobile courseware to gain the ability of the first semester students of English Study Program Politeknik Negeri Jember in pronouncing English words. This study is a collaborative classroom action research. Thirty students enrolling in Pronunciation class at English Study Program Politeknik Negeri Jember were taken as the source of data. The result showed that the materials and practices in Tflat courseware could enrich students' pronunciation learning, improve their participation, and nurture a positive attitude toward technological learning. The findings of this study also depict the potential and power of Mobile Assisted Language Learning (MALL) to encourage students to engage in classroom activities and monitor their learning. Hence, it can be concluded that MALL is pivotal and can be one alternative to facilitate students' pronunciation learning.
\end{abstract}

Keywords: pronunciation; participation; positive attitude; Tflat English Pronunciation; MALL.

\section{INTRODUCTION}

Mastery of a language, including foreign languages and in this case English provides many benefits in various aspects and fields. Moreover, globalization encourages everyone to be able to speak good English to create smooth and meaningful communication. However, to possess communication skills, one needs to go through contextual learning and training activities because communication itself involves complex processes including understanding, speaking, and listening systematically and continuously (Ahmad, 2016).

Many experts have highlighted the importance of pronunciation in communication. Pronunciation becomes a major aspect of understanding and interpreting speakers' intentions and spoken language and speakers can be considered unintelligible if they have poor pronunciation (Reed \& Lewis, 2019; Pennington \& Rogerson-Revell, 2019; Nair, Krishnasamy \& De Mello, 2017).

In the teaching of English as a Foreign Language in Indonesia, many teachers still focus more on teaching grammar than pronunciation. The students are exposed to master lexical aspects and construct linguistic structure flawlessly but not to pronounce English expressions accurately and the teaching of pronunciation is overlooked, implicitly taught and often neglected (Silalahi, 2016; Haryanto, 2015; Widagsa, Wiyanah, \& Wahyuni, 2019)

To investigate learners' proficiency in English pronunciation, the researcher conducted a preliminary study on the first-year students of the English Study Program at Politeknik Negeri Jember. It was found out that the students' English pronunciation ability was unsatisfactory. Most of them could not achieve the minimum standard passing criterion, 65 (C). Furthermore, in the teaching and learning process, the students showed a low degree of participation and motivation in pronouncing English words and utterances. The difficulties were due to several factors including students' low interest, limited vocabulary storage, first encounter with studying a language component (pronunciation) separately, and diffidence, colorless teaching strategy, and monotonous instructional media. Among those factors, the instructional media were considered one of the most vital problems since the teaching of pronunciation needs instructional media so that the students can contextualize what they are learning and acquire it better and faster.

To make the learning of pronunciation more 


\section{Alfi Hidayatu Miqawati}

Pronunciation learning, participation, and attitude enhancement through mobile assisted language learning

(MALL)

effective and interesting and to strive for intelligible and comprehensible speech, Afshari \& Ketabi 2016) emphasize the need for teaching pronunciation to gain full communicative competence and the importance of incorporating the findings of other disciplines, such as psychology, NLP, and technology. The use of many technological devices and softwares in the teaching of English has gained much attention in the recent decade.

The implementation of Mobile Assissted Language Learning (MALL) has contributed siginificantly toward students' success in learning. According to Kumar, Wotto, \& Bélanger (2018), MALL is a powerful method for engaging learners on their own terms. Klimova (2019) also stated that studying by using smartphones is effective in the enhancement of university students' performance and can be a complementary method to other forms of course delivery. More advantages of mobile learning are also highlighted by Hosseini, Ezzadeen, \& Alhazmi (2015) that it can promote an enhanced understanding of material content, costeffectiveness, game learning, and informal learning. Students also perceive mobile learning as a challenging and motivating activity (Novawan, Aisyiyah, Wijayanti, Miqawati, Indrastana, 2019).

Many studies have also addressed the effectiveness of mobile phones in language teaching and learning. Liu, Lu \& Lai (2016) analyze 24 journal articles in order to examine developments and trends in MALL. They claimed that MALL approach is beneficial present some challenges to users, academics, and teachers. However, they suggested that more research is needed to further investigate the communication that occurs among learners with the use of various mobile devices, and their developments of various cognitive learning domains.

In relation with the use of mobile phones, android-based applications or platforms have provided empirical results for assisting students' in learning English pronunciation. Arashnia \& Shahrokhi (2016) conducted an experimental study about the use of mobile learning application and they found out that students taught English pronuciation using mobile phone application outperformed those who were taught using ordinary methods (without mobile phones). Liu, $\mathrm{Xu}, \mathrm{Li}, \mathrm{Han}, \mathrm{Chen}, \mathrm{Mo}$, Chen \& Liu (2019) carried out a study about automatic speech recognition (ASR) technology in English pronunciation correction. The findings showed that ASR technology can help Chinese English learners improve their English pronunciation. Sufi \& Shalmani (2018) also found out that one courseware namely "Tflat" could improve greatly the pronunciation ability of the students. The courseware contains complete materials and exercises for students to practice and assess their English pronunciation. In the recent five years, more applications are implemented and developed to increse students' the motivation and make learning easier and more enjoyable, cure and prevent their fossilization of English pronunciation errors. And improve their overall English pronunciation and intonation (Liu, Zhu, Jiao \& Xu, 2019; Cavus, 2016; Mutqiyyah \& Muhammad, 2016).

Considering the positive effect and complete features of Tflat to the teaching of pronunciation and the need of the students to improve their English pronunciation, the researcher conducted a study on the implementation of Tflat English Pronunciation mobile courseware to enhance the ability of the first semester students of C-Class English Study Program Politeknik Negeri Jember in pronouncing English words.

\section{METHOD}

After identifying the problem through the preliminary study, the researcher conducted a Collaborative Classroom Action Research (CCAR) in C-Class (semester 1) of English Study Program Politeknik Negeri Jember which has 28 students. This design is called CCAR because 1) is done by teaching practitioners or lecturers who teach in class, 2) is applied collaboratively, and 3) aims to change a thing/overcome the problems of students in the classroom. The collaborator in this study was a lecturer who teaches Pronunciation course.

The lecturer was equipped with explanations and training before the teaching media implementation. During the learning process, the researcher filled in the field notes and the list of observations with factual data of what happened during and after the learning process. The research aims to provide a new and practical way for ELF/ESL learners to improve English pronunciation as well as provide a new mode of English pronunciation teaching for relevant educators.

Planning

At this stage, the researcher and collaborator jointly designed lesson plans, handouts, worksheets, and instruments dealing with the implementation of Tflat English Pronunciation. 
The application was chosen because it has complete activities that cover many language skills and provides ample information on how to articulate each vowel, diphthong, and consonant. Besides, once the application is downloaded, it can be accessed anytime and anywhere without any internet connection (Offline Android Application).

\section{Implementing}

The procedure of teaching was implemented in CClass of English Study Program (first semester) Politeknik Negeri Jember. There were several steps covered during the teaching and learning process. First, the students were explained how to articulate the vowels and consonants while checking the detail information and examples in Tflat English Pronunciation mobile courseware. Second, they practiced pronouncing the words. In this step, the teacher checked each student's accuracy in articulating the sounds and helped the students to overcome their difficulties when learning. Third, they had the sound details and checked whether they pronounced the words accurately or not while identifying their problems when pronouncing the words. Fourth, they recorded their voices and identified the pronunciation accuracy in the application. To gain optimum mastery, they also did the reading, writing, and listening parts in the application. The implementation stage was conducted in seven meetings.

Observing

In this step, the researcher observed the results of Tflat English Pronunciation implementation. Two kinds of data were collected; numerical data and verbal data. The numerical data were obtained from the students' pronunciation scores. Meanwhile, the results of the observation checklist, field notes, and open-ended questionnaire represent the verbal data.

There were four instruments implemented in this study; questionnaire, observation checklist, field notes, and a test. The questionnaire was used to know the students' opinions toward the implementation of Tflat English Pronunciation. In addition, the field note was used to find out the strengths and weaknesses of the application implementation. Meanwhile, to monitor the students' the students' participation and performance during the teaching and learning process, the observation checklist was employed. The last instrument employed was a test administered after the students were taught using an android-based application. Table 1 shows the students' involvement description while Table 2 shows the Pronunciation scoring rubric.

Table 1. Students' involvement description

\begin{tabular}{ccc}
\hline No & Categories & Description \\
\hline 1 & Very poor & $<20 \%$ participate \\
2 & Poor & $20 \%-40 \%$ participate \\
3 & Fair & $41 \%-60 \%$ participate \\
4 & Good & $61 \%-80 \%$ participate \\
5 & Very Good & $81 \%-100 \%$ participate \\
\hline
\end{tabular}

Table 2. Pronunciation scoring rubric

\begin{tabular}{cccc}
\hline Aspects & Poor (0-1 point) & Fair (2-3 points) & Good (3-5 points) \\
\hline Dimension & $\begin{array}{c}\text { Student makes little or } \\
\text { no effort to enunciate } \\
\text { and articulate in the } \\
\text { target language. }\end{array}$ & $\begin{array}{c}\text { The student has errors in } \\
\text { pronunciation, some } \\
\text { effort in articulation in } \\
\text { the target language. }\end{array}$ & $\begin{array}{c}\text { The student makes minor or } \\
\text { no errors in pronunciation, } \\
\text { great articulation in the target } \\
\text { language with expression. }\end{array}$ \\
\hline \multicolumn{2}{c}{ (adapted from http://www.rcampus.com/rubricshowc.cfm?code=F6W345\&sp=true) }
\end{tabular}

\section{Reflecting}

This stage involves a result analysis of the action implemented in the first cycle. The analysis was conducted by analyzing the students' learning performance and the teaching and learning process. The results were compared with the predetermined criteria of success. If one of the indicators of the criteria was not reached, the researcher would carry out the second cycle by revising the planning stage. However, if the results were appropriate, the researcher would immediately conclude the research results. Table 3 contains information about the criteria of success in this study. 
Pronunciation learning, participation, and attitude enhancement through mobile assisted language learning (MALL)

Table 3. Criteria of success

\begin{tabular}{|c|c|c|c|}
\hline Components & Criteria of Success & Data Source & Instrument \\
\hline Participation & $\begin{array}{l}90 \% \text { of the students are engaged actively in } \\
\text { the teaching and learning process. } \\
90 \% \text { of the students have positive attitudes. }\end{array}$ & $\begin{array}{l}\text { - The students' } \\
\text { involvement in } \\
\text { the classroom } \\
\text { activities }\end{array}$ & $\begin{array}{l}\text { Questionnaire } \\
\text { Observation } \\
\text { checklist } \\
\text { Field Notes }\end{array}$ \\
\hline $\begin{array}{l}\text { Learning } \\
\text { Performance }\end{array}$ & $\begin{array}{l}100 \% \text { of the students obtain a minimum } \\
\text { passing score of } 66(\mathrm{C})\end{array}$ & $\begin{array}{l}\text { The scores of } \\
\text { pronunciation } \\
\text { accuracy }\end{array}$ & $\begin{array}{l}\text { Pronunciation } \\
\text { test }\end{array}$ \\
\hline
\end{tabular}

\section{RESULTS AND DISCUSSION}

The findings of the study include the students' involvement, the students' opinion toward the implemented media, and the students' pronunciation score.

\section{Students' involvement in the classroom activities}

To obtain data about the students'involvement in the implementation of Tflat English Pronunciation mobile courseware, the observer used observation checklists and fieldnotes. The findings showed a satisfying result for the expected outcome. The summary of the students' involvement is presented in Table 4.

The information about the students' involvement was obtained from analyzing the observation checklist and field notes. From the data obtained, the observer also pinpointed some findings related to the students'involvement. In meeting 1, two points were considered as the strengths and one point as the weakness. The students were enthusiastic to pay attention to the lecturer and directly downloaded the application. Since it was their very first time learning Pronunciation, they were amazed at the features provided in the application. The students admitted that they have never known the application. When they opened the application, they could find buttons for short vowels, long vowels, double vowels (diphthongs), voiced and voiceless consonants. All students explored every single feature in the application vivaciously. The weakness found was that two students used iPhone and could not download the application. The lecturer lent him her mobile phone so that he could get engaged in the classroom activities. They identified their problems after the class and succeeded in downloading and operating the application.

Table 3. Summary of the students' involvement

\begin{tabular}{clcc}
\hline Meeting & \multicolumn{1}{c}{ Activity } & $\begin{array}{c}\text { \% of Ss' } \\
\text { Involvement }\end{array}$ & Interpretation \\
\hline 1 & Exploring the application features and manuals & 93 & Very good \\
2 & Utilizing the application (short vowels) & 97 & Very good \\
3 & Utilizing the application (long vowels) & 93 & Very good \\
4 & Utilizing the application (voiced consonants) & 93 & Very good \\
5 & Utilizing the application (voiceless consonants) & 100 & Very good \\
6 & Utilizing the application (other consonants) & 100 & Very good \\
7 & Pronunciation test & 100 & Very good \\
\hline & Class' Average Involvement & $\mathbf{9 6 , 6}$ & .
\end{tabular}

Several more strengths were also noted in meetings $2,3,4,5,6$. When utilizing the application, students learned the materials provided in the application like understanding how the sounds are articulated and practiced articulating the sounds accurately. In each meeting, all students are involved except students who did not attend the class. Since the application does not need any internet connection after being downloaded, the students could access it smoothly. In addition, the students adapted themselves fast with the application. The problem found in the meeting was several students hardly succeeded in articulating the intended sounds because they are not accustomed to articulating them or got confused as they sound similar to them. They also got difficulties in identifying and distinguishing symbols of the vowels, diphthongs, and consonants, especially when they did the listening and writing parts in the application. The observer suggested the lecturer tell the students to have more practice at home or every time they have spare time. Before the test, the students were given information related to the test to be administered so that they were prepared for the 
test. The observer did not find anything to pinpoint during the administration of the test.

Huang, Yang, Chiang, \& Su (2016) noted that mobile learning tool gain more superior results in term of students' participation and motivation. In other words, it can be concluded that MALL provides opportunities for students to actively participate in every classroom activity.

\section{Students' opinion toward the implementation of tflat English pronunciation}

The students expressed their opinion through the distributed questionnaire that showed that all of them enjoyed learning using the application. They also mentioned that the application was very useful in assisting them to learn how to pronounce words. It also gives them a new way of learning and optimizes the use of their gadgets. It corresponds positively with findings of studies conducted by GhouNane (2019); Saidouni \& Bahloul (2016); Thomas \& Munoz (2016); and White \& Mills (2014) that students showed positive attitudes towards the introduction and integration of mobile technology in language learning and any classroom activities.

\section{Students' achievement}

The last criterion of success determined was the students' learning performance. All students (30 students) needed to gain scores of more than 66 . When converted, the needed to gain at least a $\mathrm{C}$. $\mathrm{C}$ score was also the minimum requirement to pass the Pronunciation class. After the test administration, the data obtained from the writing test showed that 30 students achieved the target score, 66 . Thus, it had met the criterion of success related to the students' learning achievement.

The findings showed that the use of Tflat English Pronunciation courseware could promote the students' ability in pronouncing English words. The improvement was gained through the materials in the application and the teacher's guidance during classroom activities. Each menu in the courseware provides an ample overview and practices to help students pronounce words accurately. The finding of this study is in line with those of Arashnia \& Shahrokhi (2016) and Kim \& Kwon (2012) that giving instruction through mobile phones can help students learn pronunciation effectively and mobile applications are also effective to provide students individualized and student-centered learning opportunity.

That Mobile Assisted Language Learning (MALL) can enhance students' language skills and knowledge has been proven by other findings in the previous studies. In line with what the researcher found regarding mobile learning and language proficiency improvement, Burston (2015) pinpointed the learning outcomes of the implementations of MALL are unquestionably positive.

The optimum result of the implementation is also supported by the teacher's roles during the teaching and learning activities. In this study, the teacher actively aided the students in their effort of enunciating English words. Thus, the fact that mobile learning does not work solely to enhance students' language ability cannot be neglected. Burston (2015) supported this notion that the implementation of MALL should focus more on how technology is manipulated to affect achievement, not attribute learning gain to the technology.

Ample models and examples are given to help students identify the sound and practice of pronouncing vowels and diphthongs. The screen display is attractive and the navigation buttons are simple and easy to access. Cavus (2016), who developed an intelligent mobile application for English pronunciation teaching, also mentioned that this kind of mobile application features can make learning easier and more enjoyable than the traditional learning methods.

During learning, students could access the mobile application and asked questions whenever they found problems and difficulties and the teacher addressed them directly. Every learning activity utilizing the courseware required students' active engagement. Passive students could be more active and engaged in the learning process without any hesitance and anxiety and it is in line with Miqawati and Wijayanti (2017) argument that MALL enables students to be actively involved in the classroom pronunciation activities. Besides being more involved in the teaching and learning process, the students perceived positively toward the implementation of Tflat courseware. Thus, it can be concluded that the implementation of mobile-assisted language learning can promote the students' participation and positive attitude toward learning and it pointed out what is suggested by Kukulska-Hulme (2006) that mobile devices are representative for language learning purposes, two of which are for personal engagement and interaction as well as communication. 
Pronunciation learning, participation, and attitude enhancement through mobile assisted language learning

(MALL)

\section{CONCLUSION}

The implementation of Tflat English Pronunciation courseware can enhance the students' learning performance, boost their involvement in classroom activities, and promote a positive attitude toward the potentials of mobile technology in language learning. The findings of the study presented here showed a promising model of language teaching to adult learners using a mobile application. The findings of this study also depict the potential and power of Mobile Assisted Language Learning (MALL) to encourage students to engage in classroom activities and monitor their own learning. More exploration and experiment on the potentials of mobile-assisted learning media are eminently encouraged.

\section{REFERENCES}

teaching of pronunciation in the ESL classroom Afshari, S., \& Ketabi, S. (2017). Current trends and future directions in teaching English pronunciation. International Journal of Research Studies in Language Learning, 6(2), 83-91.

Arashnia, M., \& Shahrokhi, M. (2016). Mobile assisted language learning: English pronunciation among Iranian pre-intermediate EFL learners. Journal of Applied Linguistics and Language Research, 3(4), 149-162.

Burston, J. (2015). Twenty years of MALL project implementation: A meta-analysis of learning outcomes. ReCALL, 27(1), 4-20.

Cavus, N. (2016). Development of an intellegent mobile application for teaching English pronunciation. Procedia Computer Science, 102, 365-369.

GhouNane, N. (2019). The attitudes of second year EFL students at Dr Moulay Tahar University towards learning english pronunciation through mobile assisted language. Arab World English Journal (AWEJ), 5(Special Issue on CALL), 110123.

Haryanto, E. (2015). Teachers'corrective feedback on students'pronunciation at the daffodils English course Kampung Inggris Pare Indonesia. Linguists: Journal of Linguistics and Language Teaching, 2(2), 78-82.

Hosseini, Ebrahim S., Ezzadeen, K., \& Alhazmi, A. (2015). Acquiring knowledge through mobile applications. International Journal of Interactive Mobile Technologies, 9(3), 71-74.

Huang, C. S., Yang, S. J., Chiang, T. H., \& Su, A. Y. (2016). Effects of situated mobile learning approach on learning motivation and performance of EFL students. Journal of Educational Technology \& Society, 19(1), 263-276.

Kim, H., \& Kwon, Y. (2012). Exploring smartphone applications for effective mobile-assisted language learning. Multimedia-Assisted Language Learning, 15(1), 31-57.

Klimova, B. (2019). Impact of mobile learning on students' achievement results. Education Sciences, 9(2), 90. doi: 10.3390/educsci9020090.

Kukulska-Hulme, A. (2006). Mobile language learning now and in the future. In Svensson, P. (Ed.), From vision to practice: Language learning and IT. Sweden: Swedish Net University, 295-310.

Kumar, B. S., Wotto, M., \& Bélanger, P. (2018). Elearning, m-learning and d-learning: Conceptual definition and comparative analysis. E-Learning and Digital Media, 15(4), 191-216.

Liu, G. Z., Lu, H. C., \& Lai, C. T. (2016). Towards the construction of a field: The developments and implications of mobile assisted language learning (MALL). Digital Scholarship in the Humanities, 31(1), 164-180.

Liu, X., Xu, M., Li, M., Han, M., Chen, Z., Mo, Y., Chen, X., \& Liu, M. (2019). Improving English pronunciation via automatic speech recognition technology. International Journal of Innovation and Learning, 25(2), 126-140.

Liu, X., Zhu, C., Jiao, J., \& Xu, M. (2018, July). Promoting English pronunciation via mobile devices-based automatic speech evaluation (ASE) technology. International Conference on Blended Learning (pp. 333-343). Springer, Cham.

Miqawati, A. H., \& Wijayanti, F. (2017). Optimalisasi penggunaan flashcards melalui MALL (Mobile Assisted Language Learning) pada pengajaran pronunciation (Optimizing the use of flashcards through MALL (Mobile Assisted Language Learning) in teaching pronunciation). Prosiding.

Mutqiyyah, R., \& Muhammad, A. F. (2016). Developing mobile app of English pronunciation test using android studio. 2016 International Electronics Symposium (IES), 487-492.

Nair, R., Krishnasamy, R., \& De Mello, G. (2017). Rethinking the. The English Teacher, 14

Novawan, A., Aisyiyah, S., Wijayanti, F., Miqawati, A. H., \& Indrastana, N. S. (2019). Investigating students' MALL experience in light of an ecological perspective. Journal of English in Academic and Professional Communication, 5(2).

Pardede, P. (2018). Improving EFL students' English pronunciation by using the explicit teaching approach. JET (Journal of English Teaching), 4(3), 143-155.

Pennington, M. C., \& Rogerson-Revell, P. (2019). English pronunciation teaching and research. Londres: Palgrave Macmillan, 10, 978-988.

Reed, M., \& Levis, J. (2019). The handbook of English pronunciation. New York: John Wiley \& Sons.

Saidouni, K., \& Bahloul, A. (2016). Teachers and students' attitudes towards using mobile-assisted language learning in higher education. Arab World English Journal (AWEJ), 3(Special Issue on CALL). 
ENGLISH REVIEW: Journal of English Education

Volume 8, Issue 2, June 2020

Sharples, M., \& Spikol, D. (2017). Mobile learning. In: Duval E., Sharples M., Sutherland R. (Eds), Technology enhanced learning. Springer, Cham.

Silalahi, R. M. P. (2016). Pronunciation problems of Indonesian EFL learners: An error analysis. Journal of English Language and Culture, 6(2), 163-176.

Sufi, E., \& Shalmani, H. B. (2018). The effects of Tflat pronunciation training in Mall on the pronunciation ability of Iranian EFL learners. European Journal of Foreign Language Teaching, 3(2), 87-103.

Thomas, K., \& Munoz, M.A. (2016). Hold the phone! High school students' perception of mobile phone
p-ISSN 2301-7554, e-ISSN 2541-3643 https://journal.uniku.ac.id/index.php/ERJEE

integration in the classroom. American Secondary Education, 44(3), 19-37.

White, J., \& Mills, D. J. (2014). Examining attitudes towards and usage of smartphone technology among Japanese university students studying EFL. CALL-EJ, 15(2), 1-15.

Widagsa, R., Wiyanah, S., \& Wahyuni, P. (2019). The influence of Indonesian prosodic features on English word stress production. English Review: Journal of English Education, 7(2), 77-84.

Yudhiantara, R. A., \& Saehu, A. (2017). Mobileassisted language learning (MALL) in Indonesian Islamic higher education. IJELTAL (Indonesian Journal of English Language Teaching and Applied Linguistics), 2(1), 21-31. 
Alfi Hidayatu Miqawati

Pronunciation learning, participation, and attitude enhancement through mobile assisted language learning (MALL) 